\title{
LIGATION OF COMMON CAROTID ARTERY AND CEREBRAL BLOOD FLOW
}

(transition of $\mathrm{Po}_{0}, \mathrm{P}_{\mathrm{co}}$ and $\mathrm{pH}$ of cerebral circulating blood by the ligation of common carotid artery)

By

Kenjiro YANAGINo, Nobuo TAKASUGA, $S_{\text {ANETOMI }}$ EGUCHI and $\mathrm{T}_{\text {AKASHI }}$ FUKUSAKI

From the Dept. of Oto-Rnino-Laryngology, Nagasaki University School of Medicine. (Director: Prof. T. Goto)

Observations were made on the changes of the cerebral blood fiow caused by the ligation of the common carotid artery in 5 clinical cases and 10 dogs.

In the clinical cases, the fact was revealed that $\mathrm{PO}_{2}$ of jugular venous blood after 5 min. of ligation of the jugular vein decreased by $5 \sim 10 \%$ of the normal jugular venous blood, and $\mathrm{Po}_{\mathrm{o}}$ of jugular venous blood, and $\mathrm{Po}$ of of jugular venous blood after $1 \mathrm{~min}$. and $30 \mathrm{sec}$. of ligation of the common carotid artery decreased by $10 \sim 20 \%$ of the normal.

It is considered from this fact that if the maximum duration of ligation of the common carotid artery is $3 \mathrm{~min}$., $\mathrm{Po}_{2}$ of the carotid artery blood must be kept at $60 \sim 80 \%$ and up in radical neck surgery.

In the cases of dogs, transition of $\mathrm{Po}_{2}$ and $\mathrm{pH}$ of blood presented the same trend as that of the clinical cases, but the degrees were smaller.

\section{総頸動脈結紮の脳循環に及ぼす影響について \\ （結禁時に㧍ける脳循環血の $\mathrm{Po}_{2}, \mathrm{Pco}_{2}, \mathrm{pH}$ 変動について）}

\begin{tabular}{|c|c|c|c|c|c|c|c|}
\hline 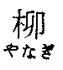 & 野 & 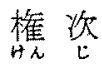 & 郎 & 高 & 賀 & 信 & $\underset{\substack{* \\
\text { 夫 }}}{*}$ \\
\hline 江 & 口 & 実 & 美 & 福 & ¿ & & \\
\hline
\end{tabular}

総頸動脈結紮術は，その術後の予期される障害のため 飞, 頸部外傷あるいは悪性腫煌における術後の大出血の 場合以外には行なるれていなかつた。

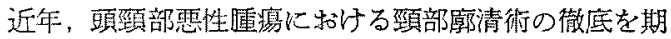
する目的で，総頸韧脈の結禁切除は試みられて扰り， 又, 形部血管外科領域でも，頸動眽閉塞症の外科的治療 法として，この方法は積極的に応用されつつある. 然る に，総頸動脈を結紮した場合の障害及びその予防などに 関する研究は極めて少なく，病理組織学的，臨床的，脳 波生理学的研究が僅が散見されるにすぎない。

著者らは総頸動脈結紮による術後の障害を子防する目 的で, 結禁開始上り終了まで代 1 週間を絽る漸進的結禁
法を行つているが，かかる結森法の妥当性を確め，改良 すべき点を知るために，臨床例及び犬による動物実験に

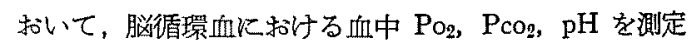
し，総頸動脈結禁が大脳呼吸汇及洼き影響について考察 を行つたので報告し，著者らの漸進的結紮法について考 按を加えたい。

\section{総頸動脈結紮法}

胸乳筇にそつて皮切を加之, 内頸静脈，総頸動脈を露 出，迷走神経をよく分離して糸をかけ，結紮を行つた。 結禁は次の段階に従つて行つた。

1. 約 50\% の結紮を行つて 4 日間経過観察

2. 4 日目飞完全結禁を行つて 3 日間観察 
3. 完全結禁後 3 日目に切断（結柇開始より7日目）

\section{測定対象及び方法}

臨床例では，上顎癌患者5例について，全身麻醉下に 下記条件時の血液を各 $5 \mathrm{cc}$ 採取した。

A. 正常時頸動脈血

B. 正常時颁静脈血

C. 頸静眽 5 分間結禁後の脳側静脈血

D. 頸動眽結禁後 30 秒から採血を始め， 1 分 30 秒ま でに採取した場合の結禁側青脈血

動物実験では，成犬10 匹を用い腹腔内臇酔下に頸部 を開き，一側の頸動脈之頸静脈を露出し，下記条件時の 血液を採取した。

1. 正常時頸動脈血

- 正常時頸静脈血

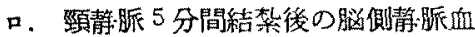

二. 颂動脈 5 分問結紫後の同側静脈血

な活，採取した血液はへパリンで凝血を防止し，流 動パラフインを重罣して血球の呼吸を防止した。 $\mathrm{Po}_{2}$, Pcog, $\mathrm{pH}$ の測定は I.L. meter によつて行つた.

\section{测定成綪}

䠦床例の成績を表（1）に，動物実験例の成績を表 (2) に示吉。更に，臨床例の $\mathrm{Po}_{2}$ を図 (1)， $\mathrm{PcO}_{2}$ を図 (2), $\mathrm{pH}$ を図 (3) に示し，動物実験に扑ける $\mathrm{P} 02$ を図 (4),

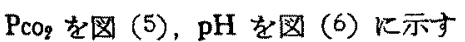

この成續から分ることは，臨床例では，頸静脈を 5 分
結禁して㷊血を起させた場合では，正常例に比して静脈 血中の $\mathrm{P}_{2}$ は $5 \sim 10 \%$ の减少があつた．澒動脈を 30 秒 結禁後から採血を開始し，1分間で埰血を行つた場合の 静脈血は正常に比し Po 10２0\% の減少が生ずること を知つた， $\mathrm{P}_{\mathrm{CO}_{2}}$ では頸静脈の結紮の場合は1.5〜2.5\% の增加，頸動脈結禁の場合は 2 3\%の增加が認められ た，動物実鍳では，各条件時の $\mathrm{Po}_{2}, \mathrm{Pco}_{2}$ の変動は臨 床例の結果と同じ傾向が認められたが，その程度は臨床 例よりも低い。

表 1 臨休例による检査成縇

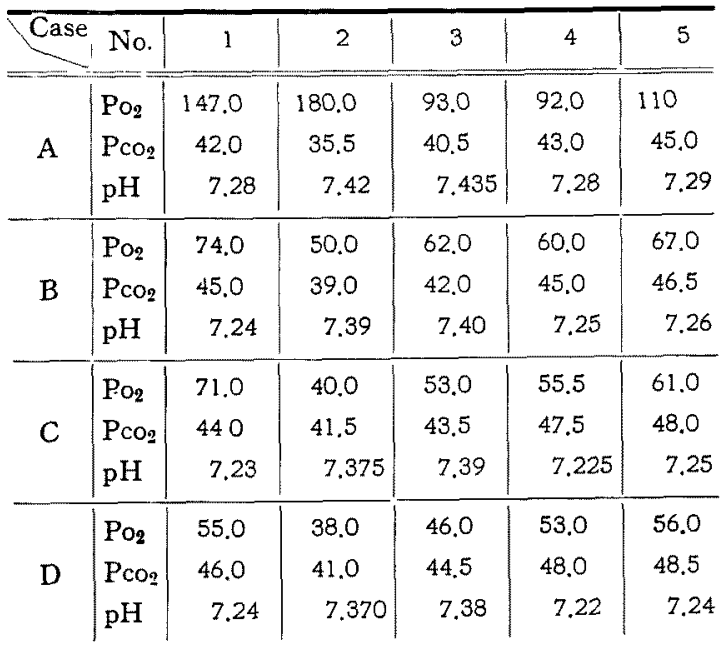

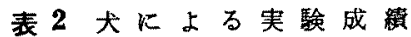

\begin{tabular}{|c|c|c|c|c|c|c|c|c|c|c|c|}
\hline Case & No. & 1 & 2 & 3 & 4 & 5 & 6 & 7 & 8 & 9 & 10 \\
\hline \multirow{3}{*}{1} & $\mathrm{Po}_{2}$ & 78.0 & 77.0 & 100.0 & 90.0 & 64.0 & 79.0 & 99.0 & 95.0 & 87.0 & 98.0 \\
\hline & $\mathrm{PCO}_{2}$ & 40.0 & 40.5 & 37.0 & 38.5 & 41.5 & 40.5 & 42.0 & 39.5 & 40.0 & 41.0 \\
\hline & $\mathrm{pH}$ & 7.315 & 7.265 & 7.29 & 7.31 & 7.28 & 7.34 & 7.29 & 7.30 & 7.27 & 7.34 \\
\hline \multirow{3}{*}{ ㅁ } & $\mathrm{Po}_{2}$ & 57.0 & 47.0 & 63.0 & 65.0 & 45.0 & 58.0 & 59.0 & 83.0 & 52.0 & 70.0 \\
\hline & $\mathrm{PCO}_{2}$ & 41.0 & 41.0 & 40.0 & 43.5 & 42.0 & 42.5 & 43.0 & 41.5 & 42.0 & 42.5 \\
\hline & $\mathrm{pH}$ & 7.31 & 7.26 & 7.28 & 7.30 & 7.27 & 7.30 & 7.26 & 7.35 & 7.275 & 7.31 \\
\hline \multirow{3}{*}{ 八 } & $\mathrm{Po}_{2}$ & 50.0 & 45.0 & 55.0 & 61.0 & 44,0 & 50.0 & 55.0 & 63.0 & 50.0 & 66.0 \\
\hline & $\mathrm{Pco}_{2}$ & 42.5 & 44.5 & 44.0 & 45.0 & 43.0 & 43.5 & 45.0 & 44.0 & 43.5 & 42.5 \\
\hline & $\mathrm{pH}$ & 7.30 & 7.23 & 7.26 & 7.26 & 7.26 & 7.28 & 7.24 & 7.33 & 7.255 & 7.31 \\
\hline \multirow{3}{*}{$=$} & $\mathrm{Po}_{2}$ & 48.0 & 43.0 & 53.0 & 61.0 & 46.0 & 48.0 & 54.0 & 63.0 & 46.0 & 64.0 \\
\hline & $\mathrm{PCO}_{2}$ & 42.5 & 45.0 & 41.5 & 46.5 & 43.5 & 44,0 & 46.5 & 45.5 & 44.0 & 43.5 \\
\hline & $\mathrm{pH}$ & 7.30 & 7.22 & 7.26 & 7.25 & 7.26 & 7.27 & 7.23 & 7.32 & 7.245 & 7,30 \\
\hline
\end{tabular}


图 1

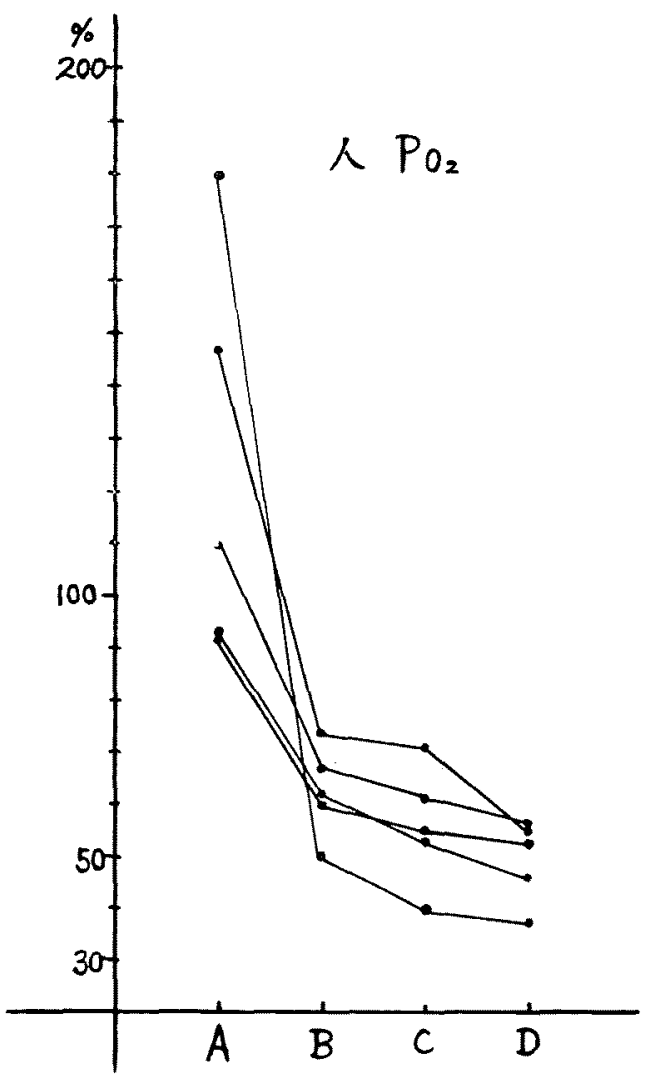

目 3

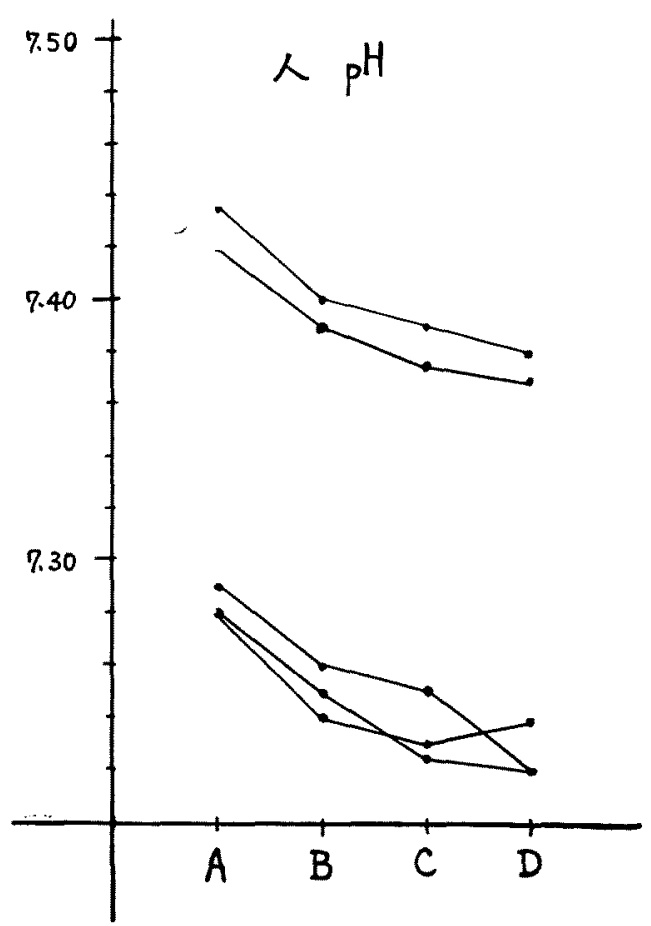

图 2

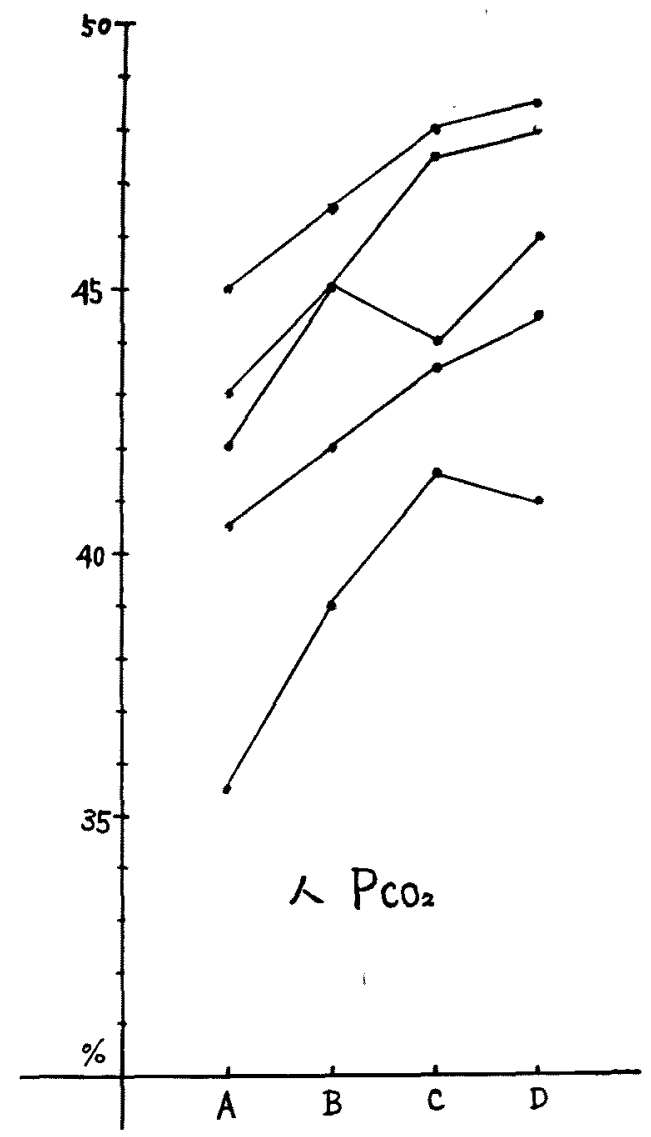

図 4

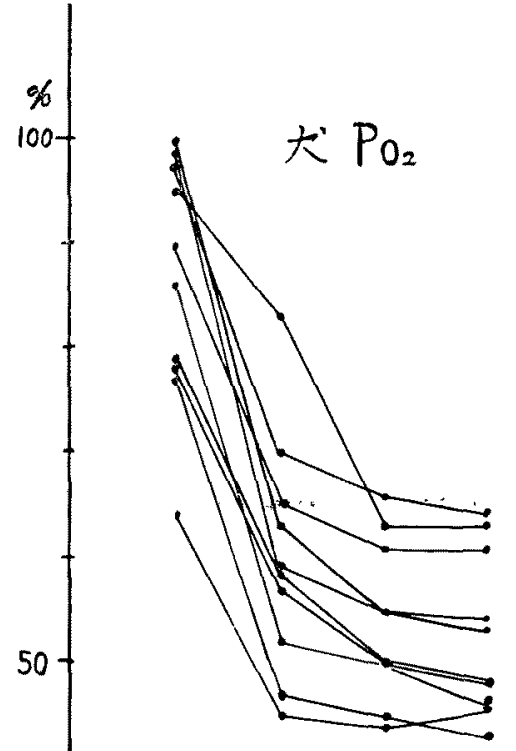


图 5

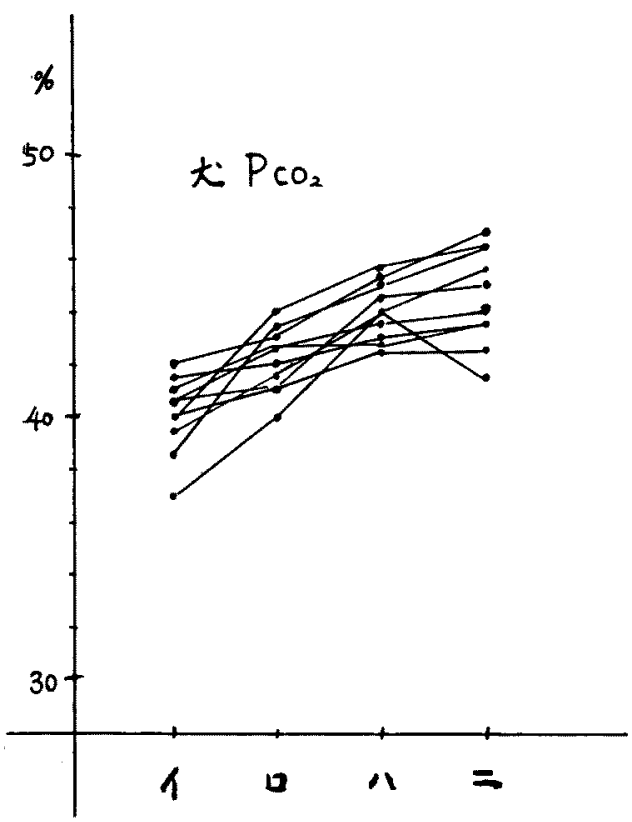

\section{総括並びに考按}

総頸動脈結等術について

総頸動脈結禁術は，古くから頸部外傷或いは術後出血 の場合に試みられていたが，積極的汇治療面に応用した 報告は椣めて少なかつた。

近年，術中及び術後の管理の進歩によつて，悪性缠痬 の徹底的な手術が行なわれるようになつたが，頭頸部悪 性腹場に括いては，頸部りンパ節転移を起している場合 が非常に多く, 頸部藏器と癒着のために, 剝離困難な症 例が少なくない，頸動脈との癒着を起している例では㩆 離ができない場合では，inoperable と見做すことが常 詶とさへもなつていた。しかし，腛瘍を頸動脈と共に除 去することができるならば，転移栄を徹底的暾清する ことができるとともに，末期に批る大出血を予防し， 放射線療法の徹底を期することができる。

癌腯が頸動脈に瘉着した例では, その進展も広く，侵 潤す強く，予後は必ずしも良好でないとする報告もある 加，著者らは inoperable として外科的処置から見放さ れた症例のらちに，1例でも多くの症例を救らことを心 掛けている。

著者らが行つている総頸動脈結紮術は，前述の如く，

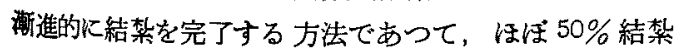
を4 日間行い，この間神経店状の発現の有無を観察し，
图 6

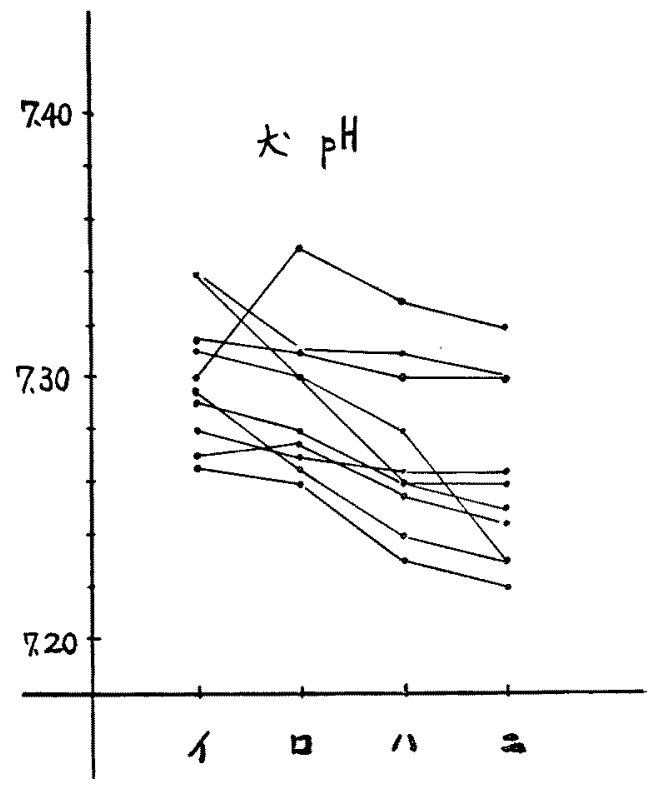

4 日目に完全結紮を行つて, 更に3日間絽過を観察し, 1 週間目に切断を行うこととしている。この方法は，側 副血行路の成立を図り，脳の無酸素状態の急激な発生を 予防寸る目的で行つている方法である。一方，頸部外科 及び血管外科領域において，注目されるようになつて来 た頸動脈閉塞症候群は，その臨床症状が多様であること は，閉塞の成立が緩除なものであるために側副血行路の 発達が関与しているものと考えられる.かかる理由で， 著者らが行つている漸進的総頸動脈結紮法が側副血行路 の発達に充分であるかどらかを知ることが，この研究の 目的であつた.

頭部血行及び側副血行路について

総頸動脈は頭部血行の主幹である. 従つて, 頸動脈を 結紮すると脳に和ける無酸素状態が急激に発生し, 脳卒 中に似大致命的な障害を起するのと思われていた。しか し，脳に和ける血行は，頭部領域に括いて幾つかの短絡 が証明されて和り，これを全しての代償血行の成立が考

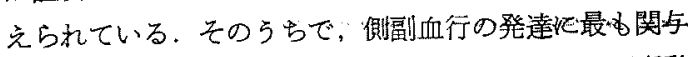
すると考えられているすのは，両側椎骨動脈から脳底動 脈を経由する経路と，健側内頸動脈から前・後交通動脈 を経由する経路との二つの経路である. 即ち図 (7) に 示す如く，一側総頸動脈を結紫しても，その支配領域の 血流が完全に阻断されることにはならない，側副血行と 
图 7 畄㕕動”脈柔

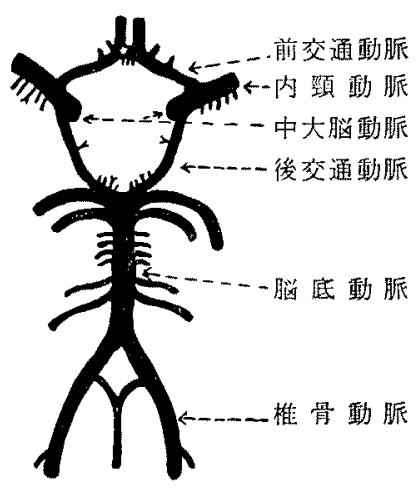

は，主血行の障害以よる機能障害を代償するために生ず る生体の機能であつて，正常時には血流が少なからた経 路が多くなつたり，Anastomose を有するものでは正常 流と逆の流れになつたりするが，主血行と同じ血量を供 給するに充分な血行ではない，しかし，側副血行路の完 全な成立ととるに，充分な血淪を得るよらになるるのと 考劣られる.このことは，頸動脈閉塞症候群のうちの， transient and recurrent type 及び slowly progressing type に扣ける発症病理によつて証明されると思われる。 しかし，频部外甥や大出血等の場合に法，救急処置とし て，総頸動脈の結禁を余儀なくされれることがる。この 場合には，結禁側に脳軟化が発生するが，臨床的には無 症状のますで経過する症例必存在する。これらの事実は 側副血行路の個人差及び血管の性状の年令差等が大きく 影響するためであると考えられている．著者らが総頸動 脈の結紮を行つた症例について得た臨床症状の多様性に ついては，綕編に発表する予定である。

測定成績について

脳は生体に取り入れられる酸素の $25 \%$ を消费すると いわれ，䉼血機序の発生とともに脳細胞は崩塄を開始す る. 全面的血行阻止によつて, 脳組織淿決定的な cata-

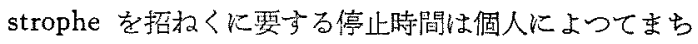
まちであって，5〜40 分のばらつきを示していると報告 されているが，これは，血行停止時の救急処置のいかん にる左右される。しかし，最も注意を要することは，最

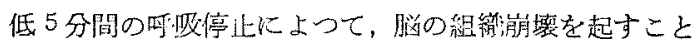
である，そこで，著者らは総靧動脈を完全絬禁して脳細 胞が irreversible とならない安全な篹团を了分と見做 して, 結禁後 30 秒から採血を始め 1 分 30 秒をで採血 を完了する方法を行い，その際の脳循環血液の酸素分
王，炭酸ガス分王，血液 $\mathrm{pH}$ を測定した。

臨床例に扮いて，頸動脈結毞前の動脈血に括いて $\mathrm{P}$ \% が 100\% 或いは 100\% 以上であつたことは，症例が人工 加压呼吸下の条件で測定を行つたためであろう. 又, 正 常時の頸動脈血 と頸静脈血之のPonの差は約 50\%であ. つた．これは脳を循環して来る間に脳において消費され た酸素を示して扣り，血中酸素の大半が消費されること を意味している．頸動脈を30 秒結皆してから採血を始 わ，1分 30 秒で採血を完了して結禁を釉つた場合は， 鳌脈血中 $\mathrm{Po}_{2}$ は正常時に較べて 10〜20\% 低下している， このことは結森してから1分30秒間に和ける循環血中 $\mathrm{PO}_{2}$ の減少を意味して扣り，側副血行路から供給される 血夜では不足していることを示している，一方，脳組織 が irreversible となる断血時間を 3 分以上とするなら ば，静脈血中 $\mathrm{P} \mathrm{O}_{2}$ は正常時に比し 20〜40\% の減少が推 測される．この值は逆に考えると，頸動脈血中 $\mathrm{Po}_{2}$ が 60〜80\% 以下となるならば，脳汇执いて irreversible な变化を茩起することであつて，頸部廓清術時の総頸動 脈結㷦では，大脳一供給される動脈血の酸素分王が 60 〜80\%以下にならないよ5にして，側副血行路の発達 を図るべきであろう.

頸静脈を結森して䇛血を起させた場合では，Po2 が5 〜10\%減少していたことは，脳内に批りる血行障害に よつて，脳の酸素消费により整血した血液の酸素が減少 したことを意味していると思われる。

炭酸ガス分圧については，頸動脈結紫による場合では $\mathrm{P}_{\mathrm{CO} 2}$ は2 3\% の增加を示していたことは断血状態のた めに增加したものであるが， $\mathrm{Pco}_{2}$ の增加は脳血管掖張 作用があり，酸素の利用率を上昇ざるから，この現象 は側副循環の発達を促し，更に，脳血流が回復し脳血流 中 $\mathrm{P}_{2}$ の上撮をきたす結果になるすのと推論される.

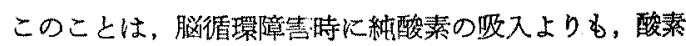
95\% と炭酸がス $5 \%$ の混合気の吸入の万が良好である ことと一致している.

動物実験で得られた成繶についてみると，臨床例と同

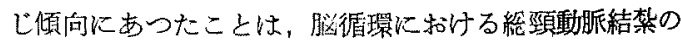
意味の重いこと老証明しているが，各測定条件時に淤 る $\mathrm{Po}_{2}, \mathrm{Pco}: \mathrm{pH}$ の变動か貼床例におけるよりる僅少で あつたことは，人類と犬との欰行路の相違によるものと 考壳られる。

\section{結語}

総頸動脈結禁の脳循罩に及ぼす影響について，臨床例

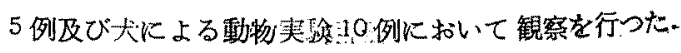


臨床例に执いては，頸静脈を 5 分間結紮すると，静脈 血中の $\mathrm{Po}_{2}$ 《正常时よりも5 10\%の減少が認められ た. 頸動脈を 30 秒結禁後から採血を始め，1 分 30 秒に 採血が完了した場合の静脈血のPogは正常に比し10 20\%の減少を生じた。このことから，頸動脈結禁によ る断血時間の安全範囲を3分以内であるとすれば，脳に 供給される血液のP Pogを60～80\%以上に保つよ5にし て侧副血行路の発達を促進すれいは，脳細織の崩壊を惹起 することを预方出来ると推測された，P 結紮では 1.5〜2.5\% の增加，頸動脈結柇では 2〜3\%の 塄加が認められた。

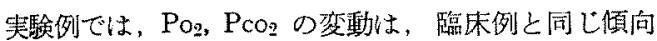

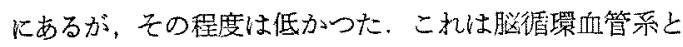
側副血行路の犬と人類との相違によるものであると考光 t.

なお，総頸動脈結紮の適示と方法の選択とには，多く の問題を残していることが明らかであるが，血中 $\mathrm{P}_{\text {c。 }}$ $\mathrm{PCO}_{2}, \mathrm{pH}$ の測定値をこの問題の参考として報告したる 第である。

\section{文献}

1)梅原芓：総預動脈結紫に起因せりと思惟される脳

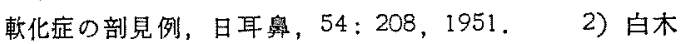
博次: 㯰環障害とくに断血過程の神経病理学, 譄と神 経, 17:213，1965.3) 吉會籍光：脳成及び推骨動 脈の閉塞とその循環不全の臨床，神経進歩，5：389，
1961. 4) J.W. Mc Call, et al.: Rupture of the Common Carotid Artery Following Radical Neck Surgery in Radiated Cases, Arch. Otolaryng. 69: 431, 1959. 5) K. Gandhi et al.: Emergency Carotid Ligation. Arch. Otolaryng. 75: 451, 1962. 6) J.J. Conley: Carotid Artery Surgery in the Treatment of Tumors of the Neck. Arch. Otolaryng. 65: 437 1957. $\quad$ 7) Fisher, M.: Occlusion of the internal carotid artery. Arch. Neurol. Psychiat. 65: 346, 1951, 8) Van Allen, M.W.: Collateral circulation to the eye in occlusion of the internal carotid artery. Arch. Neurol. 2: 74, 1960. 9)竹内一夫: 頸蜆脈閉塞症, 神経進歩, 5:511, 1961 . 10）鬼頭昭三：内頚動脈閉塞定，神経僬步，5：480，

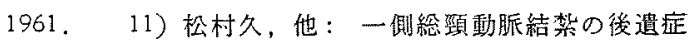
について，耳舆臨，45：434，1952，12)岩田逸夫： 䫫動脈結禁の注意について，耳堠科，27：7，1955.

本論交の要旨は昭和 39 年9月福岡にて開催 された，第16回日本気管食道科学会にて発表 した，本研究には本学第 1 外科古賀博士の御助 言のあつたことを記し謝意を表わしたい。

（原榽到着 $=$ 昭和 40.7 .7 日） 